\title{
Response of Winter-injured Peach Trees to Pruning
}

Stephen S. M iller ${ }^{1}$ and

Ross E. Byers 2

Additional index words. Prunuspersica, yield, economic return, dehorn pruning, peach canker, pruning severity

Summary. Seven-year-old 'Blake'/

'L ovell' peach [Prunus persica (L.) Batsch] trees were subjected to four pruning levels (none, light, heavy, and dehorned) each at three times (A pril, $M$ ay, and June) in a factorial arrangement following freezing injury in January 1994. Pruning had a significant effect on canopy height, canopy volume and fruit yields. Peach trees pruned in A pril or dehorned (severe pruning) had less canopy volume in the first fruiting season (1995) after the pruning treatments were initiated than trees pruned in M ay or June and light or heavy pruned trees. In 1995, yields were lower for trees pruned in June, nonpruned or dehorned trees in 1994. These treatments also produced fewer large fruit at harvest and thus reduced dollar returns per hectare in 1995. In 1996, fruit numbers and fruit sizes did not differ among treatments, but dehorned trees had lower returns per hectare because trees were smaller. The results of this study indicate that peach trees subjected to moderate winter injury should be pruned no later than 2 to 3 weeks after bloom using a heavy level of pruning. There appears to be no economic advantage to dehorn pruning even though canopy volume can be reduced resulting in a smaller

Research conducted at USDA-ARS, Kearneysville, W.Va. U se of tradenames does not imply endorsement of the products named, or criticism of similar ones not named. The cost of publishing this paper was defrayed in part by the payment of page charges. U nder postal regulations, thispaper thereforemust behereby marked advertisement solely to indicate this fact.

${ }^{1}$ Research horticulturist, U .S. D epartment of Agriculture, Agricultural Research Service, Appalachian Fruit Research Station, 45 Wiltshire Road, Kearneysville WV 25430; to whom reprint requests should be addressed.

${ }^{2} \mathrm{H}$ orticulturist and director, Virginia Polytechnic Institute and State U niversity, Alson H. Smith, Jr., Agriculture Research and Extension Center, $595 \mathrm{~L}$ aurel Grove Road, Winchester, VA 22602. 
tree with high quality wood. The results clearly illustrate the long-term negative effect of dehorn pruning on yields resulting from reduced canopy volume. M ean number of cankers per tree increased over time from 1995 through 1998, but pruning treatments did not affect the number of cankers produced. Pruning treatments did affect the size of cankers and the number with visible gumming.

ow winter temperatures can lead to bark injury in peach trees, gumming, increased incidence of leucostoma canker (Leucostoma persoonii H öhn.) (Biggs, 1989b), complete crop loss, reduced shoot growth, and/ or tree death (Greene et al., 1988). Peach treesin themiddleand northern $U$ nited States are often subjected to low winter temperatures which can result in significant damage to the buds and xylem tissue. Terminal dieback of the previous season's shoot growth and death of older weak branches is common when temperatures drop to -26
${ }^{\circ} \mathrm{C}\left(-15^{\circ} \mathrm{F}\right)$ or below. Xylem tissue may be injured or killed. Very little data exists regarding how to prune winter-injured peach trees.

Fruit trees that set fruit on 1-yearold wood respond better to heavy pruning than those that set flowerson short spurs (Westwood, 1978). Much has been written on methods for pruning peach treesand recommendationsvary widely (Ashton et al., 1950; C hilders, 1983; D ej ong et al., 1994: J ohnston and $L$ arsen, 1965; $L$ amb and $E$ dgerton, 1979; M arini, 1997; O vercash, 1988; Puls, 1983). Studies show that unusually heavy or severe pruning reduces yield ( $\mathrm{H}$ ibbard, 1948; Kappel and Bouthillier, 1995; Savage et al., 1964) and the highest yields are obtained with minimal pruning (Westwood and Gerber, 1958). H owever, most agree that healthy peach trees need a moderate level of pruning annually to maintain adequate vigor and productivity and to keep trees within a manageable size (M arini, 1997; M icke et al., 1980; Puls, 1983).

Recommendations on how to prune winter-injured peach trees vary widely among growersand researchers and data from replicated experiments to support a given approach have not been published. Gunderson (1918) evaluated several pruning methods on young, bearing peach trees following winter injury in I llinois. H e concluded that a moderate level of pruning in which last year's growth was either cut back or totally removed was the best practice resulting in better growth and fruit bud development. D ehorn pruning [heading back cuts of large limbs and/ or scaffoldsto within 46 to $61 \mathrm{~cm}$ ( 18 to 24 inches) of the trunk] severely reduced thesize of the tree, resulted in less flower bud development and, in the case of 5-year-old 'E lberta', killed the trees. Gunderson (1918) found that no pruning was better than dehorn pruning. $\mathrm{H}$ is observations were limited to the first growing season after the winter injury. In Rhode Island, Stene (1937) concluded that young winter-injured peach trees responded best, based on the amount and vigor of new growth and the color
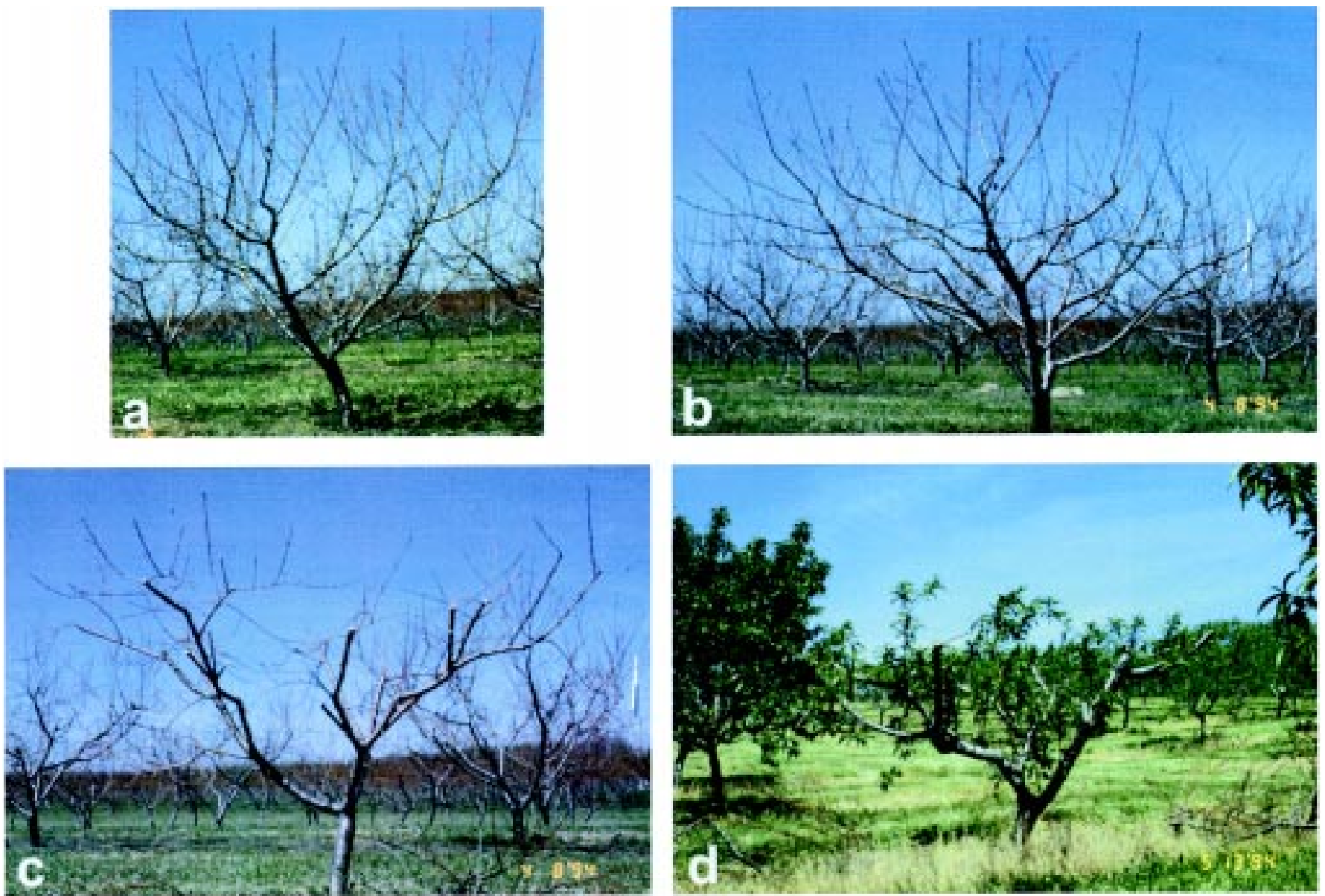

Fig. 1. Level of pruning treatments applied to winter-injured 'B lake'/'L ovell' peach trees, April to J une 1994 . (a) No pruning, (b) light pruning, (c) heavy pruning, and (d) dehorn pruning. 
and density of foliage he observed, when he pruned trees in the spring, by removing dead wood and shaping the tops. $\mathrm{H}$ e did not advise dehorning, as was recommended by some orchardists at that time. N either Gunderson (1918) or Stene (1937) provided data to support their observations. At the time of Stene's work, most orchardists were advised to prune lightly or prune only when the extent of damage could be determined after the trees had emerged from dormancy.

Childers (1983) recommended not to prune winter-injured trees or to prune lightly after growth started in the spring combined with a heavy application of nitrogen fertilizer before budbreak. J ohnston and L arsen (1965) suggested the best treatment for low temperatureinjured peach trees wasto leavethetreesunpruned. They did not advise pruning peach trees after bloom, and they raised doubts concerning the common practice of severe cutting back of bearing peach trees if low temperature injury eliminated all flower buds. Research that has focused on pruning peach trees under stress (such as peach tree short life syndrome) has shown that tree mortality is reduced when trees are pruned in the spring compared to winter (N ovember through January) (Daniell, 1973; Prince and Horton, 1972). Recently, work in $M$ ichigan indicated that delayed pruning (June or July) of winter-injured peach trees produced weaker, less desirable growth (Great Lakes Fruit Grower, 1995) compared to pruning soon after budbreak in May. H eavy pruning produced strong upright growth with less hardy shoots compared to light pruning.

In J anuary 1994, the eastern panhandle of West Virginia experienced three successive nights of temperatures near $-26^{\circ} \mathrm{C}$ or lower. There was a $100 \%$ kill of peach flower buds on trees in the region and injury to the tree's xylem tissue, although injury to vegetative buds or die back of 1993 shoots was minimal. These conditions provided an opportunity to initiate a study to examine the severity of several pruning levels applied at three times after the freeze on tree performance. Factors studied included the extent and quality of regrowth, leu costoma canker development, tree survival, fruit size, yield, and economic returnsfor several years subsequent to the injury.

\section{Materials and methods}

A block of 7-year-old 'Blake'l 'L ovell' peach trees was chosen at the Appalachian Fruit Research Station, Kearneysville, W.Va, for this study. Treeswere spaced $6 \times 6 \mathrm{~m}(20 \times 20 \mathrm{ft})$ [ 277 trees/ ha (109 trees/ acre)] with 13 trees per row and had received recommended commercial cultural practices since planting. All trees had been trained to the open center system. They were fairly uniform in size throughout the block and were considered typical, healthy peach trees for this region before J anuary 1994. The main treatment effects were 1 ) level of pruning and 2) time of pruning. The level of prunings (Fig. 1) were 1) no pruning; 2) light pruning-removing broken or dead limbs and minimal thinning out of uprights to reduce crowding; 3) heavy pruning-considered a normal or conventional level of pruning with thinning out and heading cuts of some 2-year-old or older limbs, opening centers, and renewal cuts; and 4) dehorning-asevere pruning with heading back of larger scaffold limbs [ up to $8.8 \mathrm{~cm}$ ( 3.5 inches) in diameter] to force new growth and reduce tree size. The timings selected were 1) April, at the swollen bud to half-inch green stage; 2) $M$ ay, about 14 to $21 \mathrm{~d}$ after full bloom (DAFB); and 3) J une, between 42 and 49 D AFB. Each level of pruning was applied at each of the three timings to individual trees in randomized complete blocks with 10 tree replicationsfor each treatment except dehorn pruning, which was applied only in A pril and $M$ ay with seven tree replications (due to a lack of available trees). To minimize variability due to individual pruning biases, $\mathrm{S}$. Miller performed all pruning treatments in this study. Following the initial pruning treatments in 1994, all trees received identical dormant pruning in April of each year from 1995 through 1998 using a conventional method for pruning peaches grown in this region. In practice, this corresponded to our heavy 1994 pruning treatment. $V$ isual observations regarding vigor and amount of new vegetativegrowth produced, death of shoots, leaf color, gumming and/ or canker development, and general health of the trees were periodically recorded during the 1994 growing season.

In M arch 1995, before dormant pruning, average canopy height was determined from four measurements per tree taken at the highest point on each of four sides of the canopy (two in-row sidesand two across-row sides). A quality of fruiting wood rating was assigned to each tree based on a visual examination of the tree's bearing mantle; the bearing mantle was considered to be the canopy from the ground to a height of about $2.75 \mathrm{~m} \mathrm{(9}$ $\mathrm{ft})$. A rating scale of 1 to 5 was used where a rating of 1 wasassociated with thin [ $<5 \mathrm{~mm}$ (3/16 inch) diameter], poorly colored (light brown or grayish) fruiting wood, small buds, some dead wood and a general deficiency of good diameter [ 8 to $12 \mathrm{~mm}$ ( $3 / 8$ to $1 /$ 2 inch)] fruiting wood. Wood rated 2 , 3 , or 4 had progressively larger diameter fruiting wood, less grayish black/ brown wood, larger fruit buds, and less visibledead wood. A canopy rating of 5 had medium to thick [ 8 to 12 $\mathrm{mm}$ ] new bearing shoots, good color (dark reddish brown), large fruit buds, no dead wood, and an abundance of good diameter fruiting wood. The number of pruning cuts greater than $2.5 \mathrm{~cm}$ (1 inch) in diameter and the number with visible canker symptoms (bark splitting, cracking, gumming) from the 1994 pruning cuts was recorded in M arch 1995. D ead wood in the nonpruned trees was removed and weighed at this time. A single application of $10 \mathrm{~N}-4.3 \mathrm{P}-8.3 \mathrm{~K}$ fertilizer at $348 \mathrm{~kg} \cdot \mathrm{ha}^{-1}$ (310 lb/ acre) was broadcast in late $M$ arch of each year (199498). The fresh weight of prunings was recorded for each tree in 1995 and 1996. All trees were hand thinned in early June each year of the study to space fruit 15 to $20 \mathrm{~cm}$ ( 6 to 8 inches) apart. Local recommendations were followed for all other cultural and pest management practices during the study.

In mid-J une 1995, a healthy scaffold limb was selected on half of the treatment trees and removed with a pruning saw at a point where its diameter was between 44 and $57 \mathrm{~mm}$ ( 1.75 to 2.25 inches). The open saw cut wound was coated with a commercial grade of wound dressing to prevent drying and retard any pest injury. From this severed limb a wood block was removed and the width of the annual growth (xylem tissue) was determined for 1994 and 1995 (up to mid-June) with the aid of a stereoscope and calipers. A black and white image representing the cross-sectional area of each 
wood block was made using astandard office photocopier. Thediscolored area representing the winter-injured tissue was carefully removed from the paper photocopy with scissors and the area determined with an area meter ( $\mathrm{LI}$ 3100; LI-COR, Lincoln, N eb.). Percent of tissue showing winter injury was calculated from the total crosssectional area of individual branch samples.

C anopy height, width, and depth were recorded and used to compute canopy volume at harvest. Yield effi-
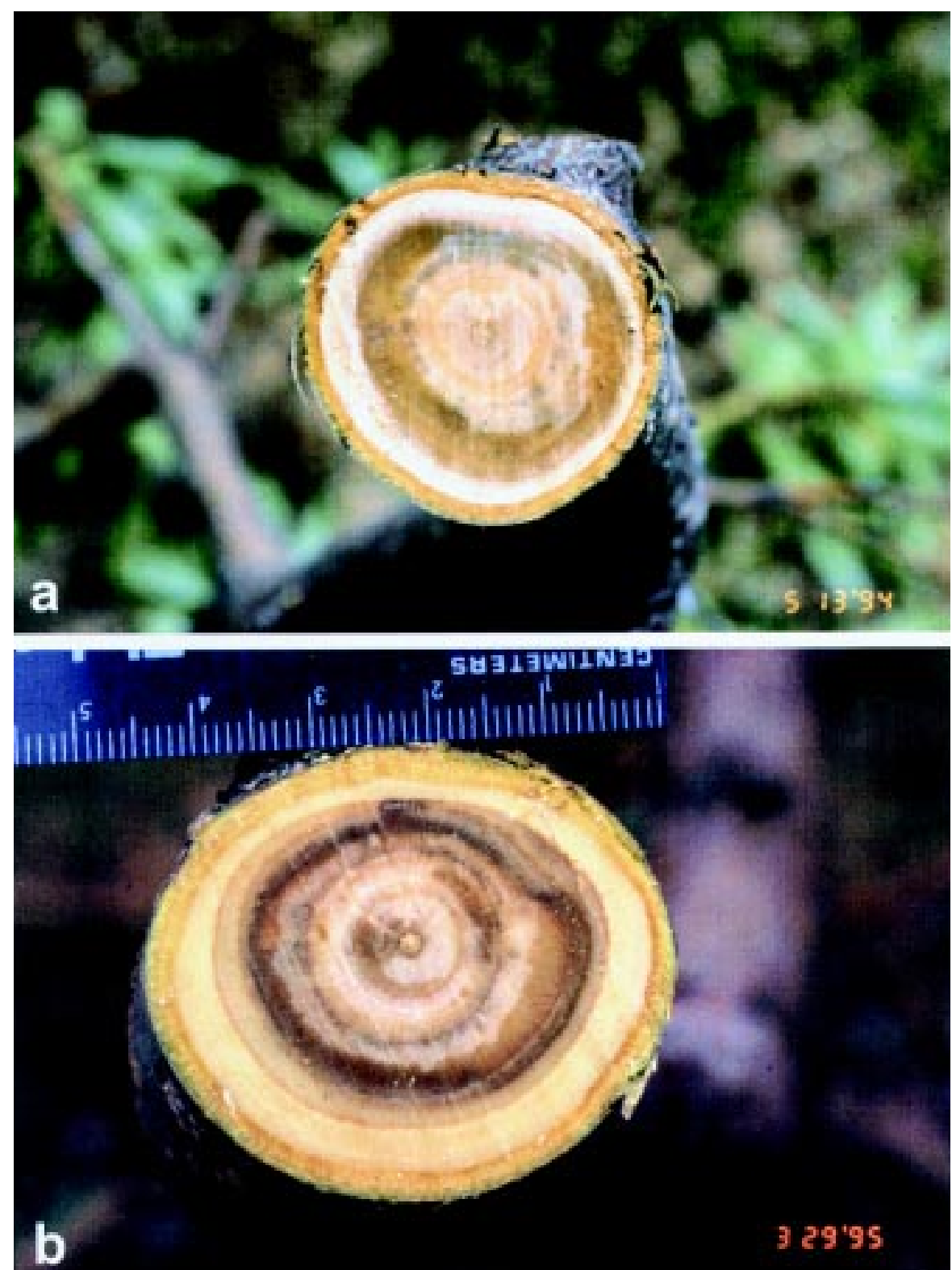

Fig. 2. Symptoms of winter injury to xylem tissue of 'Blake' peach trees sustained following three successive nights of temperatures near $-28{ }^{\circ} \mathrm{C}(-15$ ${ }^{\circ} \mathrm{F}$ ) or lower, J anuary 1994. (a) C ross-sectional view of 2-year-old branch 4 months after low temperature injury, and (b) cross-sectional view of a 4-yearold branch 14 months after winter injury.
Wayland, I nc., L aG range, Ga.). Value of the crop in 1995 was calculated using average prevailing market prices for a $17.24 \mathrm{~kg}$ (38 lb) box as reported by the USDA-AMS, Federal State $M$ arket $\mathrm{N}$ ewsfor the Appalachian Fruit District for 5 Aug. 1995. Fruit were divided into threesize categories $[>6.4$ $\mathrm{cm}$ (2.5 inch), 5.7 to $6.4 \mathrm{~cm}$ (2.25 to 2.5 inch), and 5.1 to $5.7 \mathrm{~cm} \mathrm{(2.0} \mathrm{to}$ 2.25 inch)] to determine value; fruit less than $5.1 \mathrm{~cm}$ (2 inch) in diameter was considered as having no value in this study. Beginning in 1996 and continuing through 1998 crop value was computed from prevailing market prices for a $11.34 \mathrm{~kg}(25 \mathrm{lb})$ box as reported by the U SDA M arket N ews Service for theA ppalachian D istrict for the second week in August of each year. Fruit size categories used in 1996 through 1998 were $>7.0 \mathrm{~cm}(2.75$ inch), 6.4 to $7.0 \mathrm{~cm}$ ( 2.5 to 2.75 inch), 5.7 to $6.4 \mathrm{~cm}$ (2.25 to 2.5 inch), and 5.1 to $5.7 \mathrm{~cm}$ (2.0 to 2.25 inch); no value was assigned to fruit smaller than $5.1 \mathrm{~cm}$ (2 inch) in diameter.

Leucostomacankerson main scaffold limbs and larger lateral branches were counted in M ay 1996. T wo trees per treatment, one from each of two replicated blocks, were selected for surgical removal of the cankersaccording to the techniques of Biggs (1989b) and T ravis and H ickey (1985) in J une and J uly 1996. The presence of peach tree borer and number inhabiting surgically removed cankerswere recorded. Surgically removed cankers were examined in July 1997 and classified as healed [callused over and showing no characteristics typical of leucostoma canker (Biggs, 1989b)] or not healed (exhibited fresh gumming). All data collected in the study were subjected to AN O VA and means separated using D uncan's M ultiple Range Test. Percent data wastransformed to the arcsin for analysis. Since no treatment interactions were detected, statistical comparisons are reserved for main treatment effects.

\section{Results and discussion}

At the time of pruning in 1994 the xylem tissue on all trees exhibited some degree of discoloration (generally browning), which was attributed to thelow winter temperatures of J anuary 1994 (Fig. 2). M ore than 99\% of the branches removed by pruning had discoloration to thewoody tissueranging from minor damage in the pith of 
Table 1. E ffect of time and level of pruning treatments in 7-year-old winter-injured (J anuary 1994) 'B lake'/'L ovell' peach trees on perennial cankers in 1996 and 1997 and the condition of surgically removed cankers in 1997.

\begin{tabular}{|c|c|c|c|c|c|c|c|}
\hline \multirow{2}{*}{$\begin{array}{l}\text { Pruning } \\
\text { treatment } \\
1994\end{array}$} & \multicolumn{2}{|c|}{$\begin{array}{c}\text { Perennial } \\
\text { cankers (no.) } 1996\end{array}$} & \multirow{2}{*}{$\begin{array}{c}\text { Perennial } \\
\text { cankers/ } \\
\text { tree (1997) }\end{array}$} & \multicolumn{2}{|c|}{$\begin{array}{c}\text { C anker diam }\left(\mathrm{cm}^{2}\right) \\
(\% \text { of total })\end{array}$} & \multicolumn{2}{|c|}{$\begin{array}{l}\text { \% Surgically } \\
\text { removed cankers }\end{array}$} \\
\hline & Per tree & G umming & & 2.5-5 & $\geq 5.1$ & Callused & Gumming \\
\hline \multicolumn{8}{|l|}{ Time } \\
\hline A pril & $2.8 b^{y}$ & $1.2 \mathrm{a}$ & $5.8 \mathrm{a}$ & $27 a$ & $43 a$ & $59 a$ & $41 \mathrm{a}$ \\
\hline M ay & $3.2 \mathrm{~b}$ & $0.7 \mathrm{ab}$ & $5.8 \mathrm{a}$ & $24 a$ & $55 a$ & $51 \mathrm{a}$ & $41 \mathrm{a}$ \\
\hline J une & $4.5 \mathrm{a}$ & $0.2 \mathrm{~b}$ & $7.1 \mathrm{a}$ & $\begin{array}{c}27 \mathrm{a} \\
\mathrm{P}=0.51\end{array}$ & $54 \mathrm{a}$ & $\begin{array}{c}59 a \\
P=0.20\end{array}$ & $41 \mathrm{a}$ \\
\hline \multicolumn{8}{|l|}{ Level } \\
\hline None & $3.9 \mathrm{a}$ & $0.3 \mathrm{~b}$ & $6.2 \mathrm{a}$ & $26 \mathrm{ab}$ & 58 a & $73 a$ & $27 \mathrm{~b}$ \\
\hline Light & $3.4 \mathrm{a}$ & $0.9 a b$ & $6.1 \mathrm{a}$ & $17 \mathrm{~b}$ & $62 \mathrm{a}$ & $64 \mathrm{a}$ & $35 \mathrm{ab}$ \\
\hline H eavy & $3.4 \mathrm{a}$ & $0.6 \mathrm{~b}$ & $5.5 \mathrm{a}$ & $43 a$ & $31 \mathrm{~b}$ & $61 \mathrm{a}$ & $39 a b$ \\
\hline D ehorn & $\begin{array}{c}2.3 \mathrm{a} \\
P=0.75\end{array}$ & $1.3 \mathrm{a}$ & $\begin{array}{c}7.1 \mathrm{a} \\
P=0.73\end{array}$ & $17 \mathrm{~b}$ & $49 a b$ & $12 \mathrm{~b}$ & $72 \mathrm{a}$ \\
\hline
\end{tabular}

z2.5 cm = 1 inch

yM ean separation within columns for main treatment effects by D uncan's new multiple range test, $\mathrm{P}=0.05$.

smaller shoots to major damage in the xylem tissue in larger branches. The cambial and phloem tissues showed minimal discoloration. All trees produced reasonablygood growth in 1994 following the J anuary freeze. Leaf color was medium to dark green and observationsmadein midsummer 1994 suggested that the most vigorous and best fruiting wood was associated with heavy or dehorn pruned trees. N umerous small [ $<5 \mathrm{~mm}$ (3/ 16 inch) diameter] shoots, both terminal and lateral, and a limited number of small branches failed to leaf out on the nonpruned trees in 1994, apparently a result of low temperature injury. A few additional shoots died during the 1994 growing season. The average weight of dead wood removed from the nonpruned trees in A pril 1995 was 1.3 $\mathrm{kg}(2.8 \mathrm{lb})$ per tree, which represented about $15 \%$ of thefresh weight prunings removed from these trees.

The percent of the total crosssectional area that exhibited discoloration in the excised branch samples did not differ among treatments (range of 43 to $47 \%$ ) when measured in June 1995 (datanot shown). Pruning treatmentsalso had no effect on theamount of new xylem tissue produced in 1994 or up to the date of limb sampling in June 1995 (data not shown). These findings suggested that xylem tissue was uniformly affected by thelow temperature and that pruning treatments may affect terminal shoot growth but have little or no effect on the amount of xylem wood laid down in the subsequent yearsin theolder lateral branches and permanent scaffold limbs.
The occurrence of gumming or development of leucostomacanker was limited during the 1994 growing season. At the time of pruning in Apr. 1995 and subsequently through the early growing season, there was an observed increase in the incidence of gumming and number of cankers on scaffold branches. All trees grew well in 1995 and no treesor major portions of any tree died in the second growing season after thewinter freeze. N o major scaffold limbs were lost due to cankers in 1995. A limited number of small shoots and branches continued to die in 1995 on all treatments and were removed during the dormant pruning in A pr. 1996.

When trees were evaluated for well-defined leucostoma cankers in 1996, trees pruned in June 1994 had morecankersper treethan treespruned in April or M ay 1994 (Table 1). Delayed pruning may further weaken already weak, winter-injured trees thus increasing the susceptibility to canker development. H owever, more cankers exhibited gumming on treespruned in April than trees pruned in June when observed in 1996 (Table 1). H ickey and T ravis(1985) reported morepruning wound infections on trees pruned in April than for trees pruned in J une. Their trees were without winter injury unlike the trees in this study. Level of pruning had no effect on the number of cankersproduced after two growing seasons (Table 1 ). While dehorned trees tended to have fewer cankers, these cankers exhibited more gumming (Table 1 ) than trees receiving no pruning or heavy pruning in 1994. In
1996 dehorned pruned treeshad about one-third fewer well-defined cankers than other levels of pruning (data not shown). This may be related to the moreseverepruning on dehorned trees, which led to a greater quantity of new wood that was less susceptible to invasion by canker causing organisms. Pruning treatments had no apparent effect on the number of cankersinhabited by peach tree borers (data not shown) when examined in 1996.

The average number of leucostoma cankers per tree across all treatments in 1996 was 3.4. In 1997 the average number of cankers had increased to 6.2 per tree. There were no differences in the number of cankers per tree within time or level of pruning treatments in 1997, however, there was a trend for more cankers on treespruned in J une or dehorned trees (Table 1). Time of pruning did not affect the size of cankers measured in 1997 and level of pruning had no effect on the percent of small sized cankers [2.5 cm (1 inch) diameter or less] in 1997 (data not shown). H owever, level of pruning affected the percent of medium [ 2.5 to $5.0 \mathrm{~cm}$ ( 1 to 1.9 inch)] and larger [ $5.1 \mathrm{~cm}$ (2 inch) ] sized cankers( $T$ able 1 ). $H$ eavily pruned trees had more medium sized cankers than light or dehorn pruned trees and fewer large cankers than light or nonpruned trees.

Travis and H ickey (1985) were successful in eradicating cytosporacanker [C ytospora leu costoma Fr. (anamorph $=\mathrm{L}$. persoonii $\mathrm{H}$ öhn.) ] by surgically removing the diseased tissue associated with the canker. When we 
T able 2. R esponse of 7-year-old winter-injured ( $\mathrm{J}$ anuary 1994) 'B lake'/'L ovell' peach trees to time and level of pruning in spring 1994. Data were taken before or at the time of pruning ( $2.5 \mathrm{~cm}=1 \mathrm{inch}, 1.0 \mathrm{~m}=3.3 \mathrm{ft}, 1.0 \mathrm{~kg}=2.2 \mathrm{lb}$ ).

\begin{tabular}{|c|c|c|c|c|c|c|}
\hline \multirow{3}{*}{$\begin{array}{l}\text { Pruning } \\
\text { treatment } \\
1994 \\
\end{array}$} & \multirow{3}{*}{$\begin{array}{c}\text { C anopy } \\
\text { ht (m) } \\
\text { M arch } \\
1995 \\
\end{array}$} & \multicolumn{2}{|c|}{ Pruning cuts made 1994} & \multirow{3}{*}{$\begin{array}{c}\text { Quality of } \\
\text { fruiting wood } \\
\text { in the } \\
\text { bearing mantle } \\
(1-5)\end{array}$} & \multirow{2}{*}{\multicolumn{2}{|c|}{$\begin{array}{c}\text { Fresh wt (kg) } \\
\text { in April } \\
\text { prunings }\end{array}$}} \\
\hline & & \multirow{2}{*}{$\begin{array}{c}>2.5 \mathrm{~cm} \\
\text { diam } \\
\text { (no./tree) }\end{array}$} & \multirow{2}{*}{$\begin{array}{c}\text { Visible } \\
\text { gumming and } \\
\text { cankering (\%) }\end{array}$} & & & \\
\hline & & & & & 1995 & 1996 \\
\hline \multicolumn{7}{|l|}{ Time } \\
\hline April & $2.9 b^{y}$ & $6.3 \mathrm{~b}$ & $26.9 a$ & $3.3 \mathrm{a}$ & $5.4 \mathrm{a}$ & $9.0 \mathrm{a}$ \\
\hline M ay & $3.0 \mathrm{a}$ & $7.1 \mathrm{~b}$ & $23.9 a$ & $3.1 \mathrm{a}$ & $6.4 \mathrm{a}$ & $8.9 a$ \\
\hline June & $3.0 \mathrm{a}$ & $8.8 \mathrm{a}$ & $27.2 \mathrm{a}$ & $2.3 \mathrm{~b}$ & $6.3 \mathrm{a}$ & $10.4 \mathrm{a}$ \\
\hline \multicolumn{7}{|l|}{ Level } \\
\hline None & $3.2 \mathrm{a}$ & -.- & -.- & $1.9 \mathrm{~d}$ & $8.6 \mathrm{a}$ & $9.1 \mathrm{ab}$ \\
\hline Light & $3.1 \mathrm{a}$ & $5.6 \mathrm{~b}$ & $25.0 \mathrm{~b}$ & $2.5 \mathrm{c}$ & $6.8 \mathrm{a}$ & $10.2 \mathrm{a}$ \\
\hline $\mathrm{H}$ eavy & $2.8 \mathrm{~b}$ & $8.2 \mathrm{a}$ & $25.6 \mathrm{ab}$ & $3.7 \mathrm{~b}$ & $3.8 \mathrm{~b}$ & $9.7 \mathrm{ab}$ \\
\hline Dehorn & $2.64 \mathrm{c}$ & $8.8 \mathrm{a}$ & $28.4 \mathrm{a}$ & $4.5 \mathrm{a}$ & $3.3 \mathrm{~b}$ & $7.1 \mathrm{~b}$ \\
\hline
\end{tabular}

2Rating: $1=$ new wood thin [ $<5 \mathrm{~mm}(\approx 3 / 16$ inch)], poorly colored, small buds, some dead wood, and deficiency of new wood; $5=$ abundant new wood is medium to thick in diameter [ 8 to $12 \mathrm{~mm}$ ( $3 / 8$ to $1 / 2$ inch)], good color, large buds, no dead wood.

yM ean separation within columns for main treatment effects by D uncan's new multiple range test, $P=0.05$.

surgically removed cankers from an equal and selected number of trees and cankers across all pruning treatments, time of pruning had no effect on the percent of cankers that callused or exhibited fresh gumming (Table 1). $\mathrm{H}$ owever, the percent of cankers that callused and healed among level of pruning treatments was significantly less for dehorned trees than all other treatments. T ravis and H ickey (1985) reported that surgery failed to eradicate cankers only when there was incomplete removal of diseased tissue. While we cannot rule out the potential for incomplete removal of diseased tissue, the authors feel that tree stress may be a causal factor in the lack of success to surgically remove cankers in this study.

The effect of the January 1994 freeze was readily visible in limbs removed during the normal dormant pruning in 1995 and 1996 as discoloration of the inner wood, varying from light to dark brown or black. $U$ pon examining dead shoots and branches in cross section, it was observed that those, which died, had a significant portion of dark brown wood tissue and very limited light-colored, viable wood or phloem tissue. Woody tissuein these branches was apparently unable to recover from the low temperature injury. No tree deaths occurred during this study. $\mathrm{N}$ ear the end of the third growing season (1996), one scaffold limb was lost as a result of severe canker development near the base of the limb. From 1997 through 1998, six additional trees lost at least one major scaffold limb. At the con- clusion of the study, among the seven trees with major scaffold loss, four trees lost half or more of their original canopy. Three of these trees were in the nonprune treatment; the other tree with significant canopy loss was a light prune treatment.

Trees pruned in April 1994 had a lower canopy height in M arch 1995 than trees pruned in $\mathrm{M}$ ay or June (Table2). Likewise, heavy or dehorned treesreduced canopy height compared to light pruned or unpruned trees. D ehorned trees had the lowest canopy height among all levels of pruning. A greater number of large cuts [ $>2.5 \mathrm{~cm}$ (1 inch) diameter] was made on trees pruned in J une or heavy and dehorned trees than trees pruned at the earlier timingsand lightly pruned trees ( $T$ able $2)$. Treatments resulting in greater numbers of large cuts generally had a higher percent of cutswith visiblegum- ming and in the case of the dehorned trees, the percent of cutsthat exhibited gumming wassignificantly greater than lightly pruned trees. Wilson et al. (1994) and Biggs (1989a) have demonstrated that the type of pruning cut used on peach influences the degree of cytospora (Leucostoma) canker infection. The pruning cuts used in this study were similar to flush cuts and not collar cuts that were shown to haveless cytospora infection (Wilson et al., 1984). There are no known reports relating size of pruning wounds to frequency of gumming. $\mathrm{H}$ owever, our resultssuggest that larger pruning cuts on winter-injured trees resultsin a tree that is more susceptible to gum production since the percent of cuts with gumming was greater for treatments with the greatest number of large cuts (Table 2). Weak and/ or dying wood and pruning cuts are known to be an

Table 3. Effect of time and level of pruning treatments in 7-year-old winterinjured ( $J$ anuary 1994) 'B lake'/'L ovell' peach trees on canopy volume from 1995 through $1998\left(1 \mathrm{~m}^{3}=35.3 \mathrm{ft}^{3}\right)$.

\begin{tabular}{lllll}
\hline $\begin{array}{l}\text { Pruning } \\
\text { treatment }\end{array}$ & \multicolumn{4}{c}{ Canopy vol $\left(\mathbf{m}^{3}\right)$} \\
1994 & $\mathbf{1 9 9 5}$ & $\mathbf{1 9 9 6}$ & $\mathbf{1 9 9 7}$ & $\mathbf{1 9 9 8}$ \\
\hline & & & & \\
Time & & & & \\
$\quad$ April & $37.9 \mathrm{~b}^{2}$ & $34.8 \mathrm{~b}$ & $51.1 \mathrm{~b}$ & $56.1 \mathrm{a}$ \\
M ay & $43.6 \mathrm{a}$ & $38.0 \mathrm{ab}$ & $55.3 \mathrm{ab}$ & $61.0 \mathrm{a}$ \\
$\quad$ June & $44.6 \mathrm{a}$ & $41.7 \mathrm{a}$ & $60.4 \mathrm{a}$ & $64.0 \mathrm{a}$ \\
Level & & & & \\
$\quad$ None & $41.1 \mathrm{a}$ & $39.3 \mathrm{a}$ & $56.7 \mathrm{a}$ & $63.0 \mathrm{a}$ \\
Light & $44.6 \mathrm{a}$ & $39.3 \mathrm{a}$ & $56.9 \mathrm{a}$ & $59.6 \mathrm{a}$ \\
H eavy & $44.2 \mathrm{a}$ & $40.0 \mathrm{a}$ & $55.9 \mathrm{a}$ & $62.6 \mathrm{a}$ \\
D ehorn & $32.6 \mathrm{~b}$ & $27.4 \mathrm{~b}$ & $46.4 \mathrm{~b}$ & $49.7 \mathrm{~b}$ \\
\hline
\end{tabular}

${ }^{2} M$ ean separation within columns for main treatment effects by $D$ uncan's new multiple range test, $P=0.05$. 
Table 4. . E ffect of time and level of pruning treatments in 7-year-old winter-injured (J anuary 1994) 'B lake'/'L ovell' peach trees on yield [fruit weight $(\mathrm{kg})$ and fruit number] from 1995 through 1998 ( $1 \mathrm{~kg}=2.2 \mathrm{lb}$ ).

\begin{tabular}{|c|c|c|c|c|c|c|c|c|}
\hline \multirow{3}{*}{$\begin{array}{l}\text { Pruning } \\
\text { treatment } \\
1994 \\
\end{array}$} & \multicolumn{8}{|c|}{ Mean fruit yields/tree } \\
\hline & \multicolumn{2}{|c|}{1995} & \multicolumn{2}{|c|}{1996} & \multicolumn{2}{|c|}{1997} & \multicolumn{2}{|c|}{1998} \\
\hline & (kg) & ( $\mathrm{No.}^{\circ}$ & (kg) & $\overline{(\text { No.) }}$ & (kg) & (N o.) & (kg) & (No.) \\
\hline \multicolumn{9}{|l|}{ Time } \\
\hline April & $38 a^{2}$ & $262 a$ & $56 a$ & 366 a & $57 \mathrm{~b}$ & 413 a & $57 \mathrm{~b}$ & 377 a \\
\hline M ay & $40 a$ & $285 a$ & $60 \mathrm{a}$ & 371 a & $54 \mathrm{~b}$ & $372 a$ & $63 \mathrm{ab}$ & 407 a \\
\hline June & $31 b$ & $201 \mathrm{~b}$ & $61 \mathrm{a}$ & 385 a & $62 \mathrm{a}$ & $\begin{array}{c}420 \mathrm{a} \\
P=0.21\end{array}$ & $69 a$ & $\begin{array}{c}435 a \\
P=0.48\end{array}$ \\
\hline \multicolumn{9}{|l|}{ Level } \\
\hline None & $30 \mathrm{c}$ & $184 \mathrm{C}$ & $59 a b$ & 378 a & 58 a & 396 a & $60 \mathrm{ab}$ & $375 a b$ \\
\hline Light & $38 a b$ & $253 \mathrm{~b}$ & $64 \mathrm{a}$ & 398 a & 59 a & $400 \mathrm{a}$ & $66 a$ & 448 a \\
\hline$H$ eavy & $44 \mathrm{a}$ & $326 a$ & $58 a b$ & 368 a & $60 a$ & 432 a & $69 a$ & $441 \mathrm{a}$ \\
\hline Dehorn & $34 b c$ & $242 b$ & $50 \mathrm{~b}$ & $\begin{array}{c}320 a \\
P=0.47\end{array}$ & $45 \mathrm{~b}$ & $328 \mathrm{~b}$ & $48 \mathrm{~b}$ & $287 \mathrm{~b}$ \\
\hline
\end{tabular}

zM ean separation within columns for main treatment effects by D uncan's new multiple range test, $P=0.05$.

ideal infection court for Leucostoma species that cause leucostoma canker (Biggs, 1989b).

Q uality ratings of cano py fruiting wood taken in M arch 1995 weregreater for trees pruned in April or $M$ ay than trees pruned in June (Table 2). All levels of pruning produced higher fruiting wood quality ratingsthan no pruning. Wood quality rating was greater for dehorned pruned trees than all other pruning levels. Q uality of wood rating appeared to be negatively related to canopy height ( $r=0.54 ; \mathrm{P} \leq$ 0.05 ) and in general the lower the canopy, thehigher the quality of wood. $\mathrm{N}$ ew, high quality wood in the bearing mantle area was evident where heavy or severe pruning methods lowered the canopy height.

Time of pruning had no effect on fresh weight of pruningsin 1995 (T able 2). H eavy and dehorned trees had significantly less pruning weight in 1995 than nonpruned or lightly pruned trees. Time of pruning treatmentshad no effect on the fresh weight of dormant prunings in M arch 1996; however, the level of pruning continued to affect pruning weight (Table 2). Dehorn pruned trees had the lowest pruning weight, but it only differed from the light pruned trees. Less pruning weight is a reflection of the smaller canopy for dehorn pruned trees.

Winter-injured treespruned in $\mathrm{M}$ ay or J une 1994 had more canopy volume than similar trees pruned in A pril when measured at harvest in 1995 (Table 3). Canopy volume of June pruned trees continued to exceed that for A pril pruned treeswhen measured in 1996 and 1997, but time of original pruning treatments had no effect on canopy volume when measured at harvest in 1998. D ehorned trees had the lowest canopy volume among all levels of pruning (T able 3 ). Theeffect of dehorn pruning on canopy

volume persisted through the 1998 season. The effect of time or level of pruning on canopy height was similar to the effect on canopy volume (data not shown).

Table 5. Effect of time and level of pruning treatments in 7-year-old winterinjured (J anuary 1994) 'B lake'/'L ovell' peach trees on yield efficiency $\left(\mathrm{kg} \cdot \mathrm{m}^{-3}\right.$ canopy volume) from 1995 through $1998\left(1 \mathrm{~kg} \cdot \mathrm{m}^{-3}=0.062 \mathrm{lb} / \mathrm{ft}^{3}\right)$.

\begin{tabular}{|c|c|c|c|}
\hline \multirow{2}{*}{$\begin{array}{l}\text { Pruning } \\
\text { treatment } \\
1994 \\
\end{array}$} & \multicolumn{3}{|c|}{$\begin{array}{l}\text { Yield efficiency/tree } \\
\left(\mathrm{kg} \cdot \mathrm{m}^{-3} \text { canopy vol }\right)\end{array}$} \\
\hline & 1995 & 1996 & 1997 \\
\hline \multicolumn{4}{|l|}{ Time } \\
\hline April & $1.07 a^{z}$ & $1.73 \mathrm{a}$ & $1.15 \mathrm{a}$ \\
\hline M ay & $0.97 \mathrm{a}$ & $1.70 \mathrm{a}$ & $0.98 \mathrm{~b}$ \\
\hline June & $0.72 \mathrm{~b}$ & $1.55 \mathrm{a}$ & $1.05 \mathrm{ab}$ \\
\hline \multicolumn{4}{|l|}{ Level } \\
\hline None & $0.73 c$ & $1.66 \mathrm{ab}$ & $1.04 \mathrm{a}$ \\
\hline Light & $0.89 \mathrm{bc}$ & $1.69 \mathrm{ab}$ & $1.06 \mathrm{a}$ \\
\hline H eavy & $1.04 a b$ & $1.53 \mathrm{~b}$ & $1.10 \mathrm{a}$ \\
\hline D ehorn & $1.18 \mathrm{a}$ & $1.93 \mathrm{a}$ & $1.01 \mathrm{a}$ \\
\hline
\end{tabular}

${ }^{2} \mathrm{M}$ ean separation within columns for main treatment effects by $D$ uncan's new multiple range test, $P=0.05$.

Table 6. Effect of time and level of pruning in 1994 in 7-year-old winterinjured (J anuary 1994) 'Blake'/'Lovell' peach trees on fruit size in 1995 and 1997.

\begin{tabular}{|c|c|c|c|c|}
\hline \multirow{2}{*}{$\begin{array}{l}\text { Pruning } \\
\text { treatment } \\
1994 \\
\end{array}$} & \multicolumn{3}{|c|}{$\begin{array}{c}\text { Fruit size }\left(\mathrm{cm}^{\mathrm{z}}\right) \\
1995\end{array}$} & \multirow{2}{*}{$\begin{array}{r}\text { No. of large } \\
\text { fruit (>7.0 cm) } \\
1997\end{array}$} \\
\hline & 5.1-5.7 & 5.7-6.4 & $>6.4$ & \\
\hline \multicolumn{5}{|l|}{ Time } \\
\hline April & $8 a^{y}$ & $34 a b$ & $217 a$ & $241 b$ \\
\hline M ay & 11 a & $43 a$ & $227 \mathrm{a}$ & $257 a b$ \\
\hline June & $10 a$ & $26 \mathrm{~b}$ & $162 \mathrm{~b}$ & $309 a$ \\
\hline \multicolumn{5}{|l|}{ Level } \\
\hline None & $4 \mathrm{~b}$ & $15 \mathrm{c}$ & $163 c$ & $278 a$ \\
\hline Light & $9 a b$ & $33 \mathrm{bc}$ & $208 \mathrm{~b}$ & $290 \mathrm{a}$ \\
\hline H eavy & $16 \mathrm{a}$ & $55 a$ & $248 a$ & $263 \mathrm{a}$ \\
\hline Dehorn & $9 a b$ & $36 b$ & 194 bc & $187 \mathrm{~b}$ \\
\hline
\end{tabular}

$2.5 \mathrm{~cm}=1$ inch.

yM ean separation within columns for main treatment effects by D uncan's new multiple range test, $P=0.05$. 
T able 7. Effect of time and level of pruning in 1994 in 7-year-old winterinjured (J anuary 1994) 'B lake'/'L ovell' peach trees on gross returns $(1,000$ \$U S) per hectare from 1995 through 1998 (\$1,000/ha is about \$405 per acre).

\begin{tabular}{|c|c|c|c|c|}
\hline \multirow{2}{*}{$\begin{array}{l}\text { Pruning } \\
\text { treatment } \\
1994 \\
\end{array}$} & \multicolumn{4}{|c|}{ G ross returns (U.S. \$1,000)/ha } \\
\hline & 1995 & 1996 & 1997 & 1998 \\
\hline \multicolumn{5}{|l|}{ Time } \\
\hline April & $8.3 a^{z}$ & 18.7 a & $14.7 \mathrm{ab}$ & $19.0 \mathrm{~b}$ \\
\hline M ay & $8.8 \mathrm{a}$ & $20.0 \mathrm{a}$ & $14.3 \mathrm{~b}$ & $20.8 \mathrm{ab}$ \\
\hline June & $6.8 \mathrm{~b}$ & 19.6 a & $16.7 \mathrm{a}$ & $22.3 \mathrm{a}$ \\
\hline \multicolumn{5}{|l|}{ Level } \\
\hline None & $6.6 \mathrm{c}$ & $19.6 \mathrm{ab}$ & $15.4 \mathrm{a}$ & $19.6 \mathrm{ab}$ \\
\hline Light & $8.3 \mathrm{ab}$ & $20.6 \mathrm{a}$ & 15.8 a & $22.0 \mathrm{a}$ \\
\hline H eavy & $9.5 \mathrm{a}$ & $19.4 \mathrm{ab}$ & 15.6 a & $22.2 \mathrm{a}$ \\
\hline Dehorn & $7.4 \mathrm{bc}$ & $16.2 \mathrm{~b}$ & $11.7 \mathrm{~b}$ & $16.1 \mathrm{~b}$ \\
\hline
\end{tabular}

zM ean separation within columns for main treatment effects by D uncan's new multiple range test, $P=0.05$.

Yields (weight in kg) per treewere higherfor early (A pril and $M$ ay) pruned trees and light or heavy pruned trees (Table4) and lower for trees pruned in June and for those not pruned or dehorned in 1995, the first cropping year after the winter injury. Trees pruned in J une and the unpruned (in 1994) trees had the least number of fruit per tree in 1995 (Table 4). Trees that received the heavy pruning in 1994 had 1.8 times more fruit per tree than thenonpruned treesand 1.3 times more fruit than the light or dehorn pruned treesin 1995. Time of pruning had no effect on mean fruit numbers per tree in 1996 and subsequent years of the study, but June 1994 pruned trees did have higher yields (measured astotal fruit weight) than trees pruned in A pril 1994 when measured in 1997 and 1998. While differences for yields among level of pruning treatmentswas not consistent from year to year, dehorned treesgenerally had lower yields and the fewest fruit number per tree among the level of pruning treatments (Table 4) from 1995 through the last year of the study in 1998. Yields for dehorned trees did not differ from the nonpruned trees except in 1997.

Time and level of pruning affected yield efficiency $\left(\mathrm{kg} \cdot \mathrm{m}^{-3}\right)$ in 1995 (Table 5). Yield efficiency was greater for trees pruned in A pril or $M$ ay than trees pruned in J une. $D$ ehorned trees and heavy pruned trees had higher yield efficiencies than the nonpruned trees. As severity of pruning increased, yield efficiency increased in 1995. The original time of pruning treatments had no effect on yield efficiency in 1996 or 1998 (data not shown for 1998), but trees pruned in April did have a higher yield efficiency than $M$ ay pruned trees in 1997. Yield efficiency differed only between dehorned and heavy pruned trees in 1996 and there were no differences among level of pruning treatments in 1997 or 1998 (data not shown for 1998).

When fruit was graded there were no differences among any of the pruning treatments in percent of fruit grading into selected sizeclasses in any year of the study (data not shown). We concluded, therefore, that the pruning treatments used here did not affect fruit size. However, differences did occur in the number of fruit grading into the selected size classes (T able 6). In the first cropping year (1995) after the winter injury, trees pruned in J une and nonpruned trees had fewer larger fruit than trees pruned in A pril or $M$ ay and light or heavy pruned trees, respectively. Fruit size distribution did not differ within main treatment effectsat harvest in 1996, although there was a trend to fewer large fruit for the dehorned and heavy pruned trees (data not shown). The April pruned trees had fewer large fruit than J une pruned trees and dehorned trees had the fewest number of large sized fruit among level of pruning treatments in 1997 (Table 6). In 1998 there were no differences within main treatment effects for any of the fruit size classes, however, there was a trend toward fewer large fruit in the April and the dehorn pruned trees. The number of fruit measuring $5.1 \mathrm{~cm}$ (2 inches) or less was uniform across all treatments throughout the study and generally less than 10 fruit for any tree (data not shown).

G ross returns per hectare in 1995 were highest for trees pruned in A pril or $M$ ay and trees that received either light pruning or heavy pruning in 1994 (Table 7). Higher returns for these treatments can be attributed to more fruit per tree and more large fruit per tree. In general, higher fruit numbers and thus greater economic returns appeared to be associated with pruning which encouraged production of high quality fruiting wood in the bearing mantle area. Thedwarfing effect of dehorn pruning had a negative impact on fruit number to the extent that returns per hectare were reduced for this treatment despite the high quality of bearing wood produced. The effect of time of pruning on gross returns from 1996 through 1998 was inconsistent, but in general, June-pruned trees had higher returns than $M$ ay (1997) or A pril (1998) pruned trees. Whether these differences are associated with the initial time of pruning treatments is speculative, especially sinceall trees received the same level of pruning each year from 1995 through 1998. H owever, J une pruned treesdid have higher yields in 1997 and 1998 and yieldsare obviously associated with returns. The initial level of pruning treatments continued to affect returns for the 1996 through 1998 seasons. R eturnsfor dehorned trees werelower in each of these 3 years than for light pruned trees and in 1997 and 1998 they werealso lower than heavy pruned trees. Lower returns are related to smaller sizecano pies, lower yields, and in some cases, fewer large fruit.

Results from the present study suggest that winter-injured (damage to woody tissue and near $100 \%$ bud damage) peach trees should be pruned at the time of budbreak or no later than 2 to 3 weeks after bloom. The results also indicate that a delay in pruning of winter-injured trees until June or no pruning will lower yields and the number of large fruit resulting in lower returns per hectare. D ehorn pruning of winter-injured treesshould beavoided becauseit will reduceyields and dollar returnsfor as long as 4 years after pruning primarily because of the reduction in tree size and fruit numbers, especially the larger fruit size. $L$ arge cuts used in dehorn pruning are also more prone to gumming which may increaseleucosto macanker development. D ehorn pruned trees are less responsive to surgical removal of cankers. Earlier pruning (April or $M$ ay) 
and heavy pruning produces a more desirable quality of fruiting wood than no pruning or light pruning.

\section{Literature cited}

Great Lakes Fruit Grower. 1995. H ard winter of 1994 spurs look at peach tree, shoot hardiness. G reat L akes F ruit G rower N ews 34(4):14.

Ashton, C.D., S.W. Edgecombe, R.K. Gerber, and O. Kirk. 1950. H ow to prune peach trees in U tah. U tah State Agr. Ext. Bul. 199.

Biggs, A.R. 1989a. Effect of pruning technique on leucostoma infection and callus formation over wounds in peach trees. Plant D is. 73:771-773.

Biggs, A.R. 1989b. Integrated approach to controlling leucostoma canker of peach in Ontario. Plant D is. 73:869-874.

Biggs, A.R. 1995. Leucostoma canker, p. 28-30. In: J.M. O gawa, E.I. Zehr, G.W. Bird, D.F. Ritchie, K. U riu, and J.K. $U$ yemoto (eds.). Compendium of stone fruit diseases. APS Press, St. Paul, M inn.

Childers, N .F. 1983. M odern fruit science. 9th ed. H ort. Publ., Gainesville, Fla.

Daniell, J.W. 1973. Effects of time of pruning on growth and longevity of peach trees. J. Amer. Soc. H ort. Sci. 98:383386.

Dejong, T.M ., K.R. D ay, J.F. D oyle, and R.S. J ohnson. 1994. The Kearney Agricultural Center perpendicular " $\mathrm{V}$ " (KAC-V) orchard system for peaches and nectarines. H ortT echnology 4:362-367.

Greene, II, G.M., G. Burns, R.M. Crassweller, M .R.D ickert, L.B. Forer, K.D. H ickey, L.A. H ull, B.A. J affee, C.A. Powell, C.B. Smith, and J.W. Travis. 1988. Causes of peach tree death in Pennsylvania. In: N.F. Childers and W.B. Sherman (eds.). The peach. 4th ed. Hort. Publ., Gainesville, Fla.

Gunderson, A.J. 1918. The pruning of winter-injured peach trees. Proc. Amer. Soc. H ort. Sci. 15:32-38.

H ibbard, A.D . 1948. The effect of severity of pruning on the performance of young Elberta peach trees. Proc. Amer. Soc. H ort Sci. 52:131-136

H ickey, K.D . and J.W. Travis. 1985. Effect of preventative and post-infection fungicide treatments and the time of pruning on incidence of cytospora infection on pruning wounds of peach. Proc. 1984 Stone Fruit D ecline Workshop, p. 65-70.
Johnston, S. and R.P. L arsen. 1965. Peach culture in Michigan. Mich. State Coop. Ext. Ser. Bul. 509.

Kappel, F. and M . Bouthillier. 1995. R ootstock, severity of dormant pruning, and summer pruning influences on peach tree size, yield, and fruit quality. Can. J. Plant Sci. 75:491-496.

Lamb, R.C. and L.J. Edgerton. 1979. Peach growing. N.Y. State Coll. Agr. Life Sci. Info. Bul. 44.

M arini, R.P. 1997. Pruning and canopy management practicesfor improving peach yield, fruit size, and quality. M ountaineer Grower 541:6, 8-12.

M icke, W, A.A. H ewitt, J.K. Clark, and M . Gerdts. 1980. Pruning fruit and nut trees. U niv. Calif. Coop. Ext. Ser. L flt. 21171.

O vercash, J.P. 1988. Training, pruning peach trees, southeastern U.S. In: N.F. Childers and W.B. Sherman (eds.). The peach. 4th ed. Hort. Publ., Gainesville, Fla.

Prince, V.E. and B.D. H orton. 1972. Influence of pruning at various dates on peach tree mortality. J. Amer. Soc. H ort. Sci. 97:303-305.

Puls, Jr., E. 1983. T ree training and pruning, p. 8. I n: M .E. Ferree and P.F. Bertrand (eds.). Peach growershandbook. Ga. Coop. Ext. Ser. H dbk. 1.

Savage, E.F., R.A.H ayden, and W.E. Ward. 1964. Severity of pruning Elberta peach trees as it affects growth and yield. Ga. Agr. Expt. Sta. Bul. 127.

Stene, A.E. 1937. Pruning of winter-injured peach trees. Proc. Amer. Soc. H ort. Sci. 35:147-150.

Travis, J.W. and K.D. H ickey. 1985. Efficacy of surgical removal and fungicide wound treatments on eradication of cytospora canker on peach. Proc. 1984 Stone Fruit D ecline Workshop, p. 60-64.

Westwood, M.N . 1978. Temperate zone pomology. W.H. Freeman and Co., San Francisco.

Westwood, M.N . and R.K. Gerber. 1958. Seasonal light intensity and fruit quality factors as related to the method of pruning peach trees. Proc. Amer. Soc. H ort. Sci. 72:85-91.

Wilson, C.L., S.S. M iller, B.E. O tto, and B.). Eldridge. 1984. Pruning technique affects dieback and cytospora infection in peach trees. H ortScience 19:251-253. 